\title{
Distribution of FSHR307 and FSHR680 allelic variants of FSH receptor gene exon 10 in females from Ukraine
}

\author{
G. B. Livshyts, S. S. Podlesnaja, S. A. Kravchenko, L. A. Livshits \\ Institute of Molecular Biology and Genetics of National Academy of Sciences of Ukraine \\ 150 Zabolotnogo str., Kyiv, 03680, Ukraine \\ livshits@imbg.org.ua
}

\begin{abstract}
The purpose of this study was to examine the distribution of two distinct follicle-stimulating hormone receptor (FSHR) variants, Asn680Ser and Thr307Ala, in normaly ovulated group of females from Ukraine. The FSHR gene variants, Asn680Ser and Thr307Ala, were analyzed by PCR and RFLP. The strong linkage disequilibrium between FSHR307 and FSHR680 loci was found ( $<<0.0001)$. The following genotypes have been detected: NN (33.1\%), NS (52.3\%), SS (14.6\%) for Asn680Ser variant and TT (33.1\%), TA (55.4\%), AA (11.5\%) for Thr307Ala variant. Further study on the association of FSHR variant with ovarian dysfunction and individual susceptibility to FSH-stimulation considering our population data would clarify a possible functional role of FSHR307 and FSHR680 loci.
\end{abstract}

Keywords: FSH receptor gene, polymorphisms, population.

Introduction. Follicle stimulation hormone (FSH) is one of the pituitary glycoproteins which are essential for the normal gonadal function. It coordinates and regulates gonadal growth, differentiation, endocrine function and gametogenesis in both sexes [1,2].

The effects of FSH are mediated through the binding to a specific cell surface receptor, FSHR. FSHR belongs to the large family of G-protein-coupled receptors, which span the plasma membrane seven times and transduce the biological action of FSH, using cyclic AMP (cAMP) as the main intracellular secondary messenger [3]. The FSHR gene contains a single large exon, which encodes the transmembrane and intracellular domains, and nine smaller exons which encode the extracellular domain [4].

Theoretically mutations in the FSH receptor might lead to an impaired signal transduction and thereby to a

(C) G. B. LIVSHYTS, S. S. PODLESNAJA, S. A. KRAVCHENKO,

L. A. LIVSHITS, 2008 diminished ovarian reserve. The first inactivating mutation of the FSH receptor was described in 1995 in some Finnish families with primary ovarian failure, the so-called pure gonadal dysgenesis [5]. Since this mutation was relatively frequent in the Finnish population, it was originally thought that $\mathrm{FSH}$ receptor mutations in general could constitute a common defect in ovulation failure and amenorrhea. An 'ad hoc' assay for the rapid detection of mutations was developed based on the hybridization of a labelled probe, but the successive application of such an assay to DNA samples obtained from subjects of different ethnic origin revealed a selective enrichment of the mutation only in the Finnish population, while it turned out to be extremely rare in other ethnic groups [6]. It was also clear that mutations must occur in homozygous or compound heterozygous states in order to produce a reproductive phenotype [4]. A sporadic heterozygous Val241Ala mutation found in one infertile male did not impair the receptor function in vitro [7] and it was 
judged not to be responsible for the phenotype. After the description of a few other mutations occurring spontaneously in sporadic cases of primary or early secondary amenorrhea [8], the FSH receptor mutations are commonly considered as a very rare cause of infertility.

Only one naturally occurring activating mutation of the FSH receptor has been reported in a hypophysectomized male who had normal spermatogenesis under testosterone substitution in spite of undetectable serum gonadotrophin levels [9]. No activating mutations of $\mathrm{FSH}$ receptor in the presence of normal pituitary function have been reported, suggesting that such mutations might not result in any phenotype if the pituitary gonadal axis is otherwise normal [10].

The experience of the last decade has clearly shown that mutations of the FSH receptor are very rare. This finding is consistent with the indispensable role of FSH in human reproduction, so that mutations abolishing gonadotrophin activity are self-eliminating. However, the screening of several hundreds of patients and controls world-wide led to the discovery of single nucleotide polymorphisms (SNPs) in the FSH receptor gene and to the subsequent study of the correlation between polymorphisms and gonadal function.

Today two SNPs, originally described by Aittomaki et al., are well known [5]. These two non-synonymous SNPs with frequencies of $>30 \%$ in the normal population have been identified in the coding region of exon 10 of the FSH receptor gene. The first is located at position 919 (numbering according to the translational start codon with ATG as 1 in which A is substituted by $\mathrm{G}$, changing codon 307 from threonine (ACT) to alanine (GCT)).

The second one is located at nucleotide position 2039 in which $\mathrm{G}$ is replaced by A. This leads to an amino acid change at position 680 from serine (AGT) to asparagine (AAT) [5].

The purpose of this study is to examine the distribution of two distinct FSHR gene variants, Asn680Ser and Thr307Ala, in normaly ovulated females from Ukraine.

Materials and Methods. Subjects. SNPs analysis of the FSH receptor gene was performed in 130 individuals from Ukraine after informed consent.
DNA isolation. DNA was extracted from the peripheral blood leukocytes by standard phenol-chloroform extraction method [11].

$P C R$ analysis. To analyze the FSHR transition $\mathrm{G}$ to A in position 2039 (Asn680Ser variant), polymerase chain reaction (PCR) amplification of the fragment of exon 10 was performed using specific oligonucleotide primers, as described elsewhere [12]. For the FSHR transition $A$ to $G$ in position 919 (Thr307Ala variant), PCR amplification of the exon 10 fragment was performed in one step with specific oligonucleotide primers, which were used in the second step of nested PCR, described by Sudo et al. [13].

The PCR reaction was performed in a final volume of $25 \mu$ containing $1 \times \mathrm{PCR}$ buffer, $1,5 \mathrm{mM} \mathrm{MgCl}_{2}, 200$ $\mu \mathrm{M}$ of each dNTP, $1 \mu \mathrm{M}$ of each primer, 0,2 units of Taq-DNA polymerase («BioLabTech», USA) and $200 \mathrm{ng}$ of the DNA template. The cycling conditions for Asn680Ser variant were as follows: initial denaturation at $94{ }^{\circ} \mathrm{C}$ for $5 \mathrm{~min}, 30$ cycles consisting of denaturation at $94{ }^{\circ} \mathrm{C}$ for $40 \mathrm{~s}$, annealing at $55^{\circ} \mathrm{C}$ for $40 \mathrm{~s}$, extension at $72{ }^{\circ} \mathrm{C}$ for $40 \mathrm{~s}$ and a final elongation step at $72{ }^{\circ} \mathrm{C}$ for $3 \mathrm{~min}$.

The cycling conditions for Thr307Ala variant were as follows: initial denaturation at $94{ }^{\circ} \mathrm{C}$ for $5 \mathrm{~min}, 2$ cycles consisting of denaturation at $94{ }^{\circ} \mathrm{C}$ for $45 \mathrm{~s}$, annealing at $56^{\circ} \mathrm{C}$ for $50 \mathrm{~s}$, extension at $72^{\circ} \mathrm{C}$ for $50 \mathrm{~s}, 5$ cycles consisting of denaturation at $94{ }^{\circ} \mathrm{C}$ for $45 \mathrm{~s}$, annealing at $53{ }^{\circ} \mathrm{C}$ for $50 \mathrm{~s}$, extension at $72{ }^{\circ} \mathrm{C}$ for $50 \mathrm{~s}$, 23 cycles consisting of denaturation at $94{ }^{\circ} \mathrm{C}$ for $45 \mathrm{~s}$, annealing at $51{ }^{\circ} \mathrm{C}$ for $45 \mathrm{~s}$, extension at $72{ }^{\circ} \mathrm{C}$ for $50 \mathrm{~s}$ and a final elongation step at $72{ }^{\circ} \mathrm{C}$ for $7 \mathrm{~min}$.

The PCR products were 520 and 364 bp long correspondently.

RFLP analysis of the Asn680Ser and Thr307Ala variants. The $\mathrm{G}$ to A transition in Asn680Ser variant creates a restriction site for endonuclease BseN1I. For the Thr307Ala variant a mismatch nucleotide has been introduced in one of the primers (13). This mismatch and the A to $\mathrm{G}$ transition creates an Eco81I restriction site.

The PCR products of exon 10 were digested with BseN1I for Asn680Ser variant and Eco81I for Thr307Ala variant. Digestion was performed in $15 \mu \mathrm{l}$ reaction volume containing $1 \mathrm{X}$ reaction buffer, 0,5 units of the restriction enzyme and $10 \mu \mathrm{l}$ of purified 


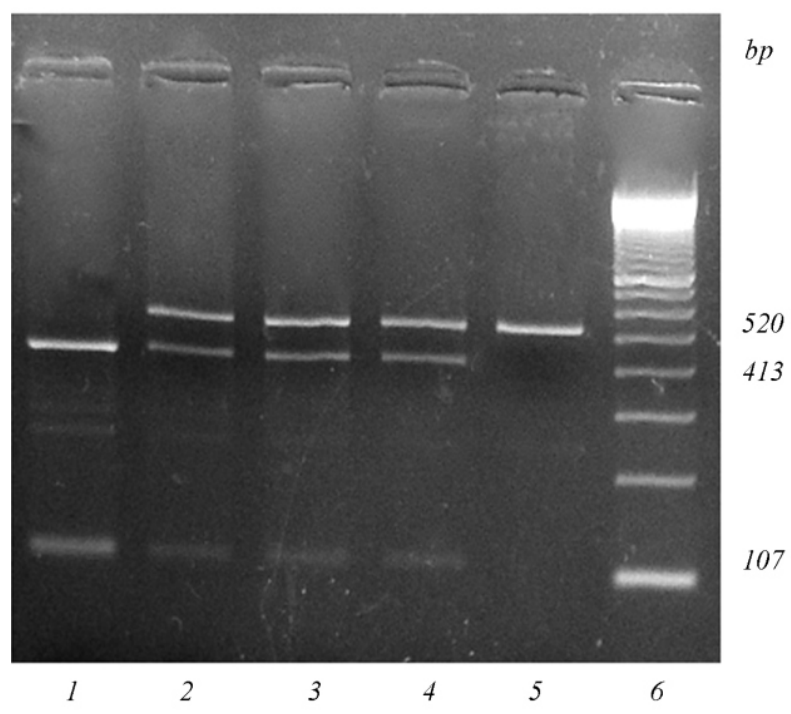

Fig. 1. RFLP analysis of Asn680Ser FSH receptor gene variant (2\% agarose gel electrophoresis): 1 - homozygote variant Ser680Ser; 2, 3, 4 - heterozygote variant Asn680Ser; 5 - homozygote variant Asn680Asn; 6-molecular mass marker (Ladder 100 bp)

PCR product, incubated at $60{ }^{\circ} \mathrm{C}$ for 2 hours for Asn680Ser variant and $37^{\circ} \mathrm{C}$ overnight for Thr307Ala variant. Restriction endonuclease digestion products with marker were visualized in $2.0 \%$ agarose gel and photographed.

Statistical analysis was performed by $\chi^{2}$ test, Fisher's exact test, likelihood-ratio test and Expectation-Maximization (EM) algorithm using GENEPOP [14] and ARLEQUIN [15] packages; $p<0.05$ was considered as significant.

Results and Discussion. Based on the RFLP analysis of Asn680Ser variant, patients were classified into three groups: NN (680Asn/Asn), NS (680Asn/Ser) and SS (680Ser/Ser). Three different patterns could be observed for Asn680Ser variant: a 520 bp band (for $680 \mathrm{Asn} / \mathrm{Asn}$ ), a $520 \mathrm{bp}$ and a $413 \mathrm{bp}$ bands (for 680 Asn/Ser), and a 413 bp band (for $680 \mathrm{Ser} / \mathrm{Ser}$ ) (Fig. 1). The following genotypes distribution has been detected: NN (33.1\%), NS (52.3\%), SS (14.6\%).

The presence of three different patterns was also observed for Thr307Ala variant: a $364 \mathrm{bp}$ band (for 307 Thr/Thr), a $364 \mathrm{bp}$ and a $328 \mathrm{bp}$ bands (for 307 Thr/Ala) and a 328 bp band (for 307 Ala/Ala) (Fig. 2). The small $36 \mathrm{bp}$ band has run out from the gel. Based on this RFLP analysis of Thr307Ala variant, patients were classified into three groups namely, TT (307Thr/Thr), TA (307Thr/Ala) and AA (307Ala/Ala).

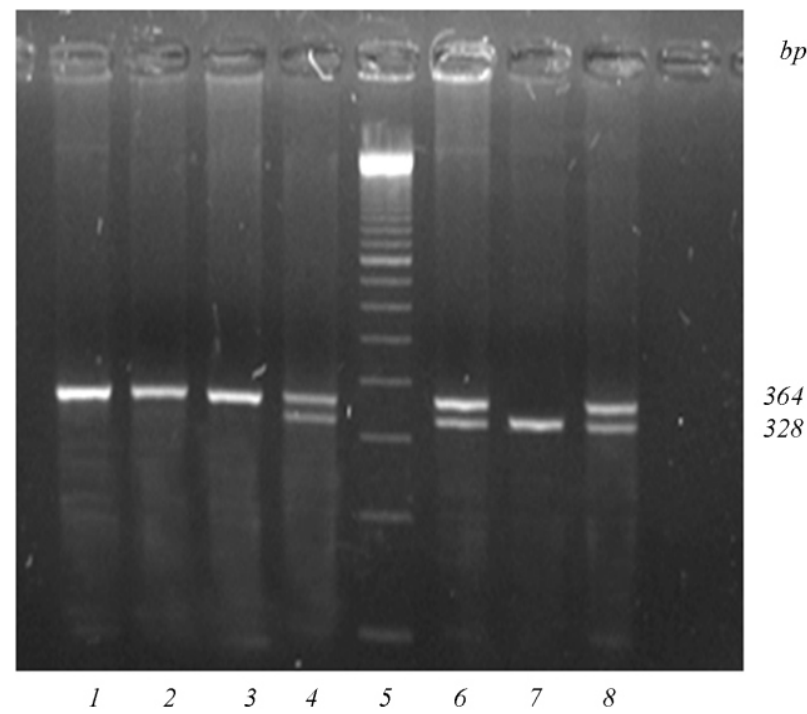

Fig. 2. RFLP analysis of Thr307Ala FSH receptor gene variant $(2 \%$ agarose gel electrophoresis): 1, 2, 3 - homozygote variant Thr307Thr; 4, 6, 8- heterozygote variant Thr307Ala; 7 - homozygote variant Ala307Ala; 5 - molecular mass marker (Ladder 100 bp)

The following distribution of genotypes has been detected: TT (33.1\%), TA (55.4\%), AA (11.5\%).

The observed genotype distributions showed no deviations from Hardy-Weinberg expectations. The strong linkage disequilibrium between FSHR307 and FSHR680 loci studied by likelihood-ratio test was revealed in the investigated group $(\mathrm{p}<0.0001)$.

Concerning two Asn680Ser and Thr307Ala polymorphic variants in exon 10 we may unite them in four possible allelic combinations, i. e. Thr307-Asn680 (allele TN), Ala307-Ser680 (allele AS), Ala307-Asn680 (allele AN) and Thr307-Ser680 (allele TS). We calculated maximum likelihood allele frequencies using EM algorithm for two loci (data shown in Table).

The distribution of several allelic variants of the FSHR gene has been described in different populations $[12,13,16]$. The analyses of FSHR variants Thr307-Asn680 (TN) and Ala307-Ser680 (AS) have demonstrated that alleles TN and AS are very common (55.1\% and $35.1 \%$ ), while the alleles AN and TS are found in Ukrainian population only in $5.7 \%$ and $4.1 \%$ correspondently.

Several studies were aimed to find correlation between the frequency distribution of FSH receptor polymorphisms and ovarian function [17-20]. The studies based on large number of patients identified a 
Distribution of FSH receptor gene alleles TN, AN, TS, and AS among populations [19, 20]

\begin{tabular}{|c|c|c|c|c|c|}
\hline Ukrainian & 130 & 55,1 & 5,7 & 4,1 & 35,1 \\
\hline Chinese & 236 & 61 & 5 & 5 & 29 \\
\hline
\end{tabular}

significant correlation between the heterozygous TN/AS genotype and polycystic ovaries (PCO) (see [18]) and between the homozygous Ser at position 680 and type II amenorrhea (according to WHO classification). Moreover, the identification of FSHR allelic variants inspired the investigation of their potential role as predictors of the ovarian response to an exogenous stimulation protocol [12]. However, in the work of Laven et al. the ovarian response after the induction of ovulation was shown to be similar for all genotypes [21]. Such contradiction may be connected to a possibly different biological meaning of Asn680Ser and Thr307Ala polymorphisms. In this study we analyzed the genotype distribution in normaly ovulated group. The observed genotype distribution in the analyzed group from Ukraine showed no deviations from Hardy-Weinberg expectations. It seems to evidence that there is no selection against any genotype in the analyzed group of normaly ovulated females. The population data, obtained here, will be used as controls for further study on the association of the FSHR variants with ovarian dysfunction and individual susceptibility to FSH-stimulation to clarify a possible functional role of Asn680Ser and Thr307Ala polymorphisms.

Acknowledgments. We thank the staff at the clinic ISIDA and clinic NADIJA for their kind assistance in collecting the blood samples.

\section{Г. Б. Лівшиць, С. С. Подлєсна, С. А. Кравченко, Л. А. Лівщиияь}

Розподіл поліморфних варіантів локусів FSHR307 та FSHR680 10-го екзона гена FSHR у групі жінок з України

Резюме

Проаналізовано розподіл поліморфних варіантів Asn680Ser $i$ Thr307Ala гена рецептора фолікулостимулювального гормону (FSHR) у жінок з нормальною овуляцією з Украӥни. Поліморфні варіанти гена FSHR досліджували методами ПЛР- та ПДРФ-аналізу. Виявлено нерівновагу за зчепленням між локусами FSHR307 ma FSHR680 ( $<$ 0,0001). Ідентифіковано гено- типи NN (33,1\%), NS (52,3\%), SS (14,6\%) для варіанта Asn680Ser ma TT (33,1 \%), ТА (55,4\%), АA (11,5\%) - для варіанта Thr307Ala. Зважаючи на отримані популяційні дані, подальше вивчення асоціації поліморфних варіантів гена FSHR з дисфункцією яєчників та індивідуальною чутливістю до FSH-стимуляиії, можливо, допоможе визначити функиіональну роль локусів FSHR307 ma FSHR680.

Ключові слова: ген FSHR, поліморфізм, популяція.

\section{А. Б. Ливщии, С. С. Подлесная, С. А. Кравченко, Л. А. Ливщии}

Распределение полиморфных вариантов локусов FSHR307 и FSHR680 10-го экзона гена FSHR в группе женщин из Украины

Резюме

Проанализировано распределение полиморфных вариантов Asn680Ser и Thr307Ala гена рецептора фоликуллостимулирующего гормона (FSHR) в группе женщиин с нормальной овуляцичей из популяции Украины. Полиморфные варианты Asn680Ser u Thr307Ala гена FSHR исследовали методами ПЦР- и ПДРФ-анализа. Выявлено неравновесие по сиеплению между локусами FSHR307 и FSHR680 ( $p<0,0001)$. Идентифиичрованы генотипы NN (33,1\%), NS (52,3\%), SS (14,6\%) для варианта Asn680Ser и TT (33,1\%), TA (55,4\%), AA (11,5\%) - для варианта Thr307Ala. Основываясь на популячионных данных, дальнейшее изучение ассоциации полиморфных вариантов гена FSHR c дисфункциями яичников и индивидуальной чувствительностью к FSH-стимуляиии, возможно, прояснит функииональную роль локусов FSHR307 и FSHR680.

Ключевые слова: ген FSHR, полиморфизм, популяция.

\section{REFERENCES}

1. Gharib S. D., Wierman M. E., Shupnik M. A., Chin W. W. Molecular biology of pituitary gonadotropins // Endocrinol. Rev.-1990.-11.-P. 177-199.

2. Moyle W. R., Campbell R. K. Gonadotropins // Reproductive endocrinology, surgery and technology / Eds E. Y. Adashi, J. A. Rock, Z. Rosenwalks.-Lippincott-Raven, 1996.P. 683-724.

3. Segaloff D. L., Ascoli M. The lutropin/choriogonadotropin receptor: 4 years later// Endocrinol. Rev.-1993.-14.-P. 324342.

4. Simoni M., Gromoll J., Nieschlag E. The follicle-stimulating hormone receptor: biochemistry, molecular biology and pathophysiology // Endocrinol. Rev.-1997.-18.-P. 739-773.

5. Aittomaki K., Lucena J. L., Pakarinen P., Sistonen P., Tapanainen J., Gromoll J., Kaskikari R., Sankila E. M., Lehvaslaiho H., Engel A. R., Nieschlag E., Huhtaniemi I., de 
la Chapelle A. Mutation in the follicle-stimulating hormone receptor gene causes hereditary hypergonadotropic ovarian failure // Cell.-1995.-82, N 6.-P. 959-968.

6. Jiang M., Aittomaiki K., Nilsson C., Pakarinen P., Iitia A., Torresani T., Simonsen H., Goh V., Pettersson K., de la Chapelle $A$. The frequency of an inactivating point mutation $(566 \mathrm{C} \rightarrow \mathrm{T})$ of the human follicle-stimulating hormone receptor gene in four populations using allele-specific hybridization and time-resolved fluorometry // J. Clin. Endocrinol. Metab.-1998.-83.-P. 4338-4343.

7. Simoni M., Gromoll J., Hoppner W., Kamischke A., Krafft T., Stahle D., Nieschlag E. Mutational analysis of the follicle-stimulating hormone (FSH) receptor in normal and infertile men: identification and characterization of two discrete FSH receptor isoforms // J. Clin. Endocrinol. Metab.-1999.-84.-P. 751-755.

8. Beau I., Touraine P., Meduri G., Gougeon A., Desroches A., Matuchansky C., Milgrom E., Kuttenn F., Misrahi M. A novel phenotype related to partial loss of function mutations of the follicle stimulating hormone receptor // J. Clin. Invest.-1998.-102.-P. 1352-1359.

9. Gromoll J., Simoni M., Nieschlag E. An activating mutation of the follicle-stimulating hormone receptor autonomously sustains spermatogenesis in a hypophysectomized man // J. Clin. Endocrinol. Metab.-1996.-81.-P. 1367-1370.

10. Simoni J. M. Keeping it up: maintaining adherence to antiviral therapies // Body Posit.-1998.-11, N 4-5.-P. 2023.

11. Maniatis T., Fritsch E. F., SambrookJ. Molecular cloning: a laboratory manual.-New York: Cold Spring Harbor Lab. press, 1982.-545 $\mathrm{p}$.

12. Laven J. S., Mulders A. G., Suryandari D. A., Gromoll J., Nieschlag E., Fauser B. C., Simoni M. Follicle-stimulating hormone receptor polymorphisms in females with normogonadotropic anovulatory infertility // Fertility and Sterility.-2003-80.-P. 986-999.

13. Sudo S., Kudo M., Wada S., Sato O., Hsueh A. J., Fujimoto S. Genetic and functional analyses of polymorphisms in the human FSH receptor gene // Mol. Hum. Reprod.-2002.-8, N 10.-P. 893-899.

14. Raymond M., Rousset F. GENEPOP (version 1.2): population genetics software for exact tests and ecumenicism // J. Heredity.-1995.-86.-P. 248-249.
15. Excoffier L., Laval G., Schneider S. Arlequin ver. 3.0: An integrated software package for population genetics data analysis // Evolution. Bioinform. Online.-2005.-1.-P. 4750 .

16. Loutradis D., Patsoula E., Minas V., Koussidis G. A., Antsaklis A., Michalas S., Makrigiannakis A. FSH receptor gene polymorphisms have a role for different ovarian response to stimulation in patients entering IVF/ICSI-ET programs // J. Assist. Reprod. Genet.-2006.-23, N 4.-P. 177184.

17. Da Fonte K. M. B., Batista M. C., Russel A. J., Vass K., Giacaglia L. R., Mendonca B. B., Latronico A. C. No evidence of the inactivating mutation (C566T) in the follicle-stimulating hormone receptor gene in Brazilian females with premature ovarian failure // Fertility and Sterility.-1998-70.-P. 565-567.

18. Liu J. Y., Gromoll J., Cedars M. I., La Barbera A. R. Identification of allelic variants in the follicle-stimulating hormone receptor genes of females with or without hypergonadotropic amenorrhea // Fertility and Sterility.1998-70.-P. 326-331.

19. Conway G. S., Conway E., Walker C., Hoppner W., Gromoll $J$., Simoni M. Mutation screening and isoform prevalence of the follicle stimulating hormone receptor gene in females with premature ovarian failure, resistant ovary syndrome and polycystic ovary syndrome // Clin. Endocrinol.-1999.-51.-P. 97-99.

20. Tong Y., Liao W. X., Roy A. C., Ng S. C. Absence of mutations in the coding regions of the follicle-stimulating hormone receptor gene in Singapore Chinese females with premature ovarian failure and polycystic ovary syndrome // Hormone Metab. Res.-2001.-33.-P. 21-26.

21. Perez M. M., Gromoll J., Behre H. M., Gassner C., Nieschlag E., Simoni M. Ovarian response to Follicle-Stimulating Hormone (FSH). Stimulation depends on the FSH receptor genotype // J. Clin. Endocrinol. Metabol.-2000.-85.-P. 3365-3369.
УДК $575.11+577.21$

Надійшла до редакції 04.02.08 